\title{
BRAZILIAN SPOTTED FEVER: A REEMERGENT ZOONOSIS
}

\author{
GRECA H. (1), LANGONI H. (1, 2), SOUZA L.C. (1)
}

(1) Department of Veterinary Hygiene and Public Health, School of Veterinary Medicine and Animal Husbandry, São Paulo State University - UNESP, Botucatu, São Paulo State, Brazil; (2) Center for Zoonosis Research - NUPEZO, UNESP, Botucatu, São Paulo State, Brazil.

ABSTRACT: Brazilian spotted fever is caused by the bacterium Rickettsia rickettsii, which is the most pathogenic species of the spotted-fever rickettsiae group and is transmitted by the bite of infected ticks. Amblyomma cajennense is the most important tick species involved in the cycle of this zoonosis in Brazil as it presents low host specificity, great number of natural reservoirs and wide geographic distribution. It was first described in the state of São Paulo in 1929 and later in Rio de Janeiro, Minas Gerais and Bahia. The number of cases decreased in the 1940's with the development of new plague control techniques and antibiotics. In the last decades, the number of new cases has increased. The current review aimed at reporting some of the epidemiological and public health aspects of this reemergent disease with new foci, mainly in the southeastern region of Brazil.

KEY WORDS: Brazilian spotted fever, Rickettsia rickettsii, Amblyomma cajennense.

CONFLICTS OF INTEREST: There is no conflict.

\section{CORRESPONDENCE TO:}

HÉLIO LANGONI, Departamento de Higiene Veterinária e Saúde Pública, Faculdade de Medicina Veterinária e Zootecnia, UNESP, Distrito de Rubião Jr., s/n, 18.618-000, Botucatu, SP, Brasil. Phone: + 55143811 6270. Fax: + 55143811 6075. Email: hlangoni@fmvz.unesp.br. 


\section{INTRODUCTION}

Brazilian spotted fever is a zoonosis whose etiological agent circulates between ticks and mammals, independently of the participation of men. It is caused by Rickettsia rickettsii, an obligate intracellular Gram-negative bacterium that also causes Rocky Mountain spotted fever in North America $(4,15)$. According to Galvão et al. (11), Brazilian spotted fever is the ricketsial infection that presents the highest lethality rates in Brazil, with greater importance in certain areas.

In Brazil, the first case was described in 1929 in São Paulo State, and later in Minas Gerais, Bahia and Rio de Janeiro States. In the 1980's, there were some suspect cases in the region of Campinas, São Paulo State, but only two were confirmed by indirect fluorescent antibody test (IFAT) in 1987 (5). Since then, spotted fever has been considered a reemergent disease, and areas previously regarded as free of this zoonosis are now endemic. An example is Coronel Pacheco, district of Juiz de Fora, Minas Gerais State, where 65 new cases were recorded between 2001 and 2004 (12).

Brazilian spotted fever occurs in humans due to the bite of infected ticks, which are the natural reservoirs and vectors of the disease $(20,29)$. Amblyomma cajennense, known as "star tick", is the main species. This affirmative is based on many isolates of $R$. rickettsii from this species of ticks in the states of Minas Gerais and São Paulo, as well as in some other countries such as Mexico, Panama and Colombia, and on epidemiological associations in endemic areas infested by $A$. cajennense. Some studies have demonstrated that the agent survives all growth stages of the tick and that there is vertical transmission. Other tick species are both transmitters and vectors: A. aureolatum, Rhipicephalus sanguineus, Dermacentor andersoni and D. variabilis (12). Spotted fever manifests abruptly with initial flu symptoms, including shiver, fever, apathy, myalgia and migraine. Cutaneous eruptions are noticed between the second and the sixth days in the extremities, spreading to the rest of the body with the evolution of clinical signs. A conclusive diagnosis based on the symptoms might be difficult to make, similarly to other infectious processes; therefore, the epidemiological aspects of this zoonosis should also be taken into consideration (20). 


\section{OBJECTIVE}

The present review aimed at reporting some significant aspects related to spotted fever as a reemergent zoonosis, alerting to the importance of its epidemiology for diagnosis.

\section{LITERATURE REVIEW}

\section{HISTORY}

Among all diseases affecting men, ricketsial infections have caused the greatest suffering and the highest number of deaths. In 1899, in the United States, the clinical manifestations of Rocky Mountain spotted fever were described by Maxcy $(14,19)$. In 1909, Ricketts (25) reported that the tick was the vector of the disease, after observing successful transmission to guinea pigs (Cavia porcellus) and finding the agent in tissue smear of ticks. He also suggested the participation of wild animals in the disease cycle. However, Magalhães \& Moreira (19), in 1939, were the first to isolate the agent from the blood of opossum (Didelphis marsupialis) in guinea pigs and experimentally reproduce the disease. They also had important participation in confirming that $A$. cajennense is a natural reservoir of the agent, and that there are bacterium-vector relationship, vertical transmission, transtadial transmission, and naturally infected ticks. Other important aspect is the need of vertebrate reservoirs to maintain the bacteria in nature $(14,19)$.

Spotted fever was described in the suburban areas of the capital of São Paulo State in 1929. It was named "exanthematic typhus of São Paulo" and its agent, $R$. brasiliensis. In the same year, José Toledo Piza (24) started distinguishing between spotted fever and the other exanthematic diseases in Brazil. In 1933, extensive research indicated the existence of cross-immunity between the agent of exanthematic typhus ( $R$. brasiliensis) and that of the Rocky Mountain spotted fever ( $R$. rickettsii), allowing the conclusion that $R$. rickettsii was the agent of both diseases (11).

With the development of insecticides, vector control techniques and antibiotics during the Second World War, there were great advances in the treatment of ricketsial infections (14). Data about the occurrence of the disease from this period until the 1980's are scarce (17); dozens of cases were reported between the 1950's and the 1980's, and all patients were from the Emilio Ribas Hospital, São Paulo, Brazil. Most patients resided in the rural zone next to São Paulo, like Diadema, Santo André and 
Mogi das Cruzes. New cases have been reported, showing the importance of spotted fever, especially in Brazil (5).

\section{ETIOLOGICAL AGENT}

Rickettsia rickettsii (Figure 1) belongs to the spotted-fever group rickettsiae, which are genetically related but have different surface antigenic proteins. Rickettsia rickettsii is the most pathogenic species, although virulence varies with the strain (1, 33).

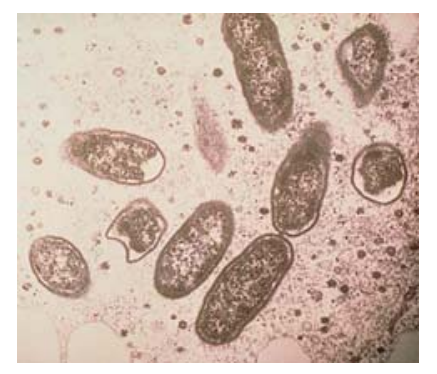

Figure 1. Electron microscopy of Rickettsia rickettsii (21).

It is a highly-adapted obligate intracellular bacterium that has developed transportation and metabolic systems and usually lives in the cytosol or, less often, in the nucleus of its host cell. Its cell wall is constituted of peptidoglycans containing muramic and diaminopimelic acids, resembling the cell wall of Gram-negative bacteria. This microorganism multiplies by binary fission and, in cell culture, its generation time ranges from eight to ten hours at a temperature of $34^{\circ} \mathrm{C}$. Rickettsia rickettsii is pleomorphic and might present cocci or short rod forms, in pairs, isolated or as filaments. Its size usually ranges from 0.3 to $1.0 \mu \mathrm{m}$. Rickettsiae can be easily visualized under optical microscope when stained with Giemsa, which provides blue coloration, or with Macchiavello, which provides red coloration contrasting with the blue-stained cytoplasm $(3,21,33)$.

Among the protein antigens of $R$. rickettsii, two surface proteins (190 and 135kDa) contain heat-labile epitopes, which are species-specific, and other proteins that are common to several members of the group. Antibodies against lipopolysaccharides do not provide protection against experimental infection in animals (33). 


\section{VECTORS AND RESERVOIRS}

In the United States, the main vectors are the ticks $D$. variabilis and $D$. andersoni, especially in the Rocky Mountain region $(9,22)$. In Brazil, A. cajennense (Figure 2), popularly known as "star tick" or "horse tick" is considered the main vector $(8,23)$. It is the most important species in the transmission of spotted fever, as it has wide geographic distribution, parasites a great number of domestic and wild animals, including men, and can be found throughout the year (29).

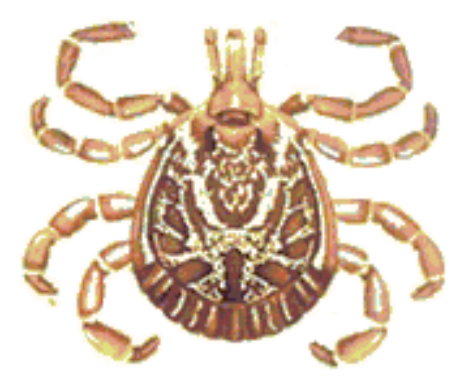

Figure 2. Amblyomma cajennense, the main species in the transmission of Brazilian spotted fever (29).

During the life cycle of $A$. cajennense, fertilized and engorged females detach from the reservoir and fall onto the vegetation and the soil, where the oviposition period begins (approximately 12 days), originating about 50 thousand eggs. After an incubation period of about 30 days at $25^{\circ} \mathrm{C}$, the eggs hatch and the hexapod larvae are born, moving over or under the vegetation, according to environmental variations, until they find their first host. In the host, they feed on lymph, blood or digested tissue during three to six days; then, they fall off the reservoir, searching for protection on the soil, where ecdysis occurs, and become nymphs. The octopod nymphs attach to a new host and keep engorging for five to seven days, and as in the larval period, they find protection on the soil and in 23-25 days undergo a new ecdysis, becoming adult ticks which, in approximately one week, will be ready to parasite new hosts (26, 32).

Once in the host, the adult ticks (males and females) feed on tissue and blood and reproduce. Fertilized females keep engorging for ten days, then detach from the host and begin a new generation. Transtadial transmission occurs and, in most of the cases, if the egg is infective, larvae, nymphs and adults will present rickettsiae, allowing transovarian transmission, at least for one generation $(23,27)$. 
After a primary infection, a tick remains infected for its whole life. If periodic reinfection is not possible, rickettsiae tend to disappear after some generations (23). Numerous populations of $A$. cajennense in endemic areas are very common due to their low host specificity and to the possibility of transmitting the agent in all their three evolutive stages (27).

The influence of climatic and environmental factors regulate, in most part, the population dynamics of such vectors, making possible a definitive moment of intervention to break the installed parasitic cycle. Important socioeconomic aspects are more evident when both the evolution of the Brazilian population and the increase in equine and bovine breeding are analyzed. This indicates that the increase in reservoir populations provides $A$. cajennense with a source of nutrition, resulting in its growth (26).

Ticks are not only vectors, but also reservoirs, as they are potentially capable of keeping infected during months or years to wait for a host. The transovarian cycle or vertical transmission is the main responsible for keeping the agent in nature because it allows the pathogen dissemination to thousands of larvae of subsequent generations (23).

In Brazil, capybara (Hydrochoerus hydrochaeris) is considered the agent reservoir in nature as its capability to keep the agent circulating, without causing the clinical signs of the disease, was experimentally demonstrated (14). The agent was also isolated from opossums (Didelphis marsupialis), dogs (Canis familiaris) and wild rabbits (Sylvilagus spp.) $(1,6,14)$.

\section{TRANSMISSION}

Transmission occurs by the ticks' bite and regurgitation of contaminated saliva, or when the host scratches lesions containing contaminated $A$. cajennense feces ( 9 , 31).

The number of human cases is directly associated with the population of vectors, as the higher the number of ticks in a certain region, the higher are the chances of infestation and human parasistism by an infected tick (23).

\section{PATHOGENESIS}

Brazilian spotted fever presents an average incubation period of seven days (2-14 days) (28), which is directly related to the amount of inoculated bacteria (16). After 
inoculation, the microorganisms are phagocited, escaping to the cytosol and multiplying until they destroy the host cell. Rickettsiae present an endotoxin but do not release it, and $R$. rickettsii activates the host's kallikrein and kinin, causing local clotting (9).

Cutaneous lesions appear due to the agent proliferation in the endothelium, causing thrombus, hemorrhage, perivascular infiltration and focal necrosis. In the skin, myocardium and brain tissues, typhoid nodules are formed (31).

Differently, $R$. rickettsii does not multiply adequately to break the host cells. However, during multiplication, cytotoxic enzymes are produced, causing multifocal lesions in the endothelium which, once altered, favors the adherence of platelets, resulting in clotting disturbance. These factors together lead to vascular disturbances, resulting in edema and hemorrhage, followed by decreased venous return, decreased tissue blood perfusion, and tissue alterations (23).

\section{CLINICAL SIGNS}

The main clinical signs of spotted fever are fever, nausea, vomit, migraine and myalgia. Spots appear from the third to the fifth day, along with fever. They start in the palm of the hands (Figure 3) and sole of the feet, spreading through the members to the thorax and abdomen. When the spots reach such magnitude, the clinical status is already severe and prognosis is not favorable (23).

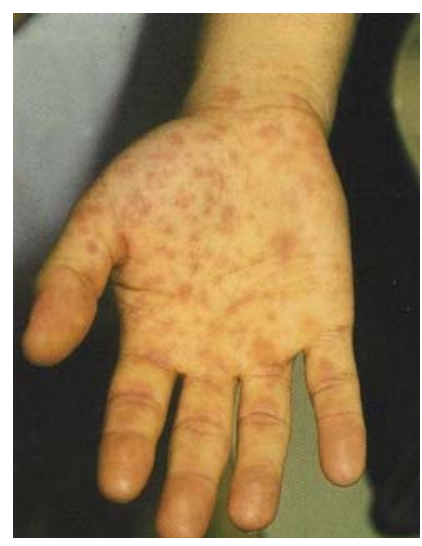

Figure 3. Spots in the palm of the hand of a Rocky Mountain spotted fever patient (18).

The disease evolves seriously for two or three weeks, when there is necrosis in hemorrhagic suffusion areas due to the generalized vasculitis. The face becomes 
congested and infiltrated, with periocular edema and conjunctivitis. Cough, arterial hypotension and increase in the number of cells in fluids are common. Increase in the size of liver and spleen (little noticed), and neurological sequels such as behavioral and learning disturbances frequently occur in children (31).

Hyperthermia with temperature around $39^{\circ} \mathrm{C}$ and migraines are usually intense and constitute the reason why most patients look for medical care. Myalgia occurs because of intense rhabdomyolysis and multiple focal necrosis (16).

The disease evolves quickly to toxemia, hyperemia and conjunctival congestion. Exanthema is a late and very suggestive sign of the disease, manifesting between three and five days after the fever. Fever, exanthema and migraine compose the classic triad that appears only in $3 \%$ of patients when the illness starts. Exanthema begins with erythematous maculae of $1-5 \mathrm{~mm}$ diameter which evolve to maculopapular lesions and petechias $(2,16)$.

The disease progresses to the central nervous system (CNS), lungs and kidneys if not early diagnosed and treated. The most common sign in compromised CNS is mental confusion and lethargy which allows unfavorable prognosis, mainly during coma and convulsions (16).

Alteration in vascular permeability leads to dehydration with hypovolemia, altered renal function resulting in renal failure, azotemia and, in some cases, acute tubular necrosis $(16,33)$. It occurs because of the high protein loss, which justifies the generalized edema observed in many cases (9).

Severe acute respiratory syndrome (SARS) is the main cause of death for spotted fever patients. In the classic form of the disease, death may occur between eight and fifteen days after the emergence of clinical signs, if not correctly treated; in the most severe forms, death may occur in one to five days after the first signs, making diagnosis difficult (16).

On the other hand, in most of the wild reservoirs, infection is not apparent. Both experimentally and naturally infected dogs can present many clinical signs, among which the most common are: fever, lethargy, depression, anorexia, edema (lips, scrotum, prepuce, ears and extremities), cutaneous lesions, spontaneous bleeding (epistaxis, melena and hematuria), altered breathing frequency, ataxia, conjunctivitis, episcleral congestion, generalized lymphadenopathy, liver and spleen enlargement, myalgia, arthralgia, and cardiac arrhythmia $(1,13,30)$. 


\section{DIAGNOSIS}

\section{CLINICAL DIAGNOSIS}

During clinical examination, epidemiological precedents must be investigated, as well as the epidemiological situation of the home region and places visited by the patients in the previous 15 days. In rainy seasons, it is important that differential diagnosis of leptospirosis be based on similar clinical signs (like fever, myalgia and migraine) for typhoid fever, malaria by Plasmodium falciparum, septicemias by other agents, measles, enterovirus infections, hemorrhagic fever, arbovirus infection, and toxoplasmosis $(16,31)$.

The history of exposure to ticks is extremely important, but it must be clear if the exposure occurred in the urban or in the rural zone, as in urban areas the tick that parasites dogs is $R$. sanguineus and, in rural zones, the prevalent ticks belong to the Amblyomma genus, including $A$. cajennense, $A$. aureolatum, $A$. tigrinum, $A$. ovale, $A$. brasiliensis, and A. cooperi (10).

\section{LABORATORY DIAGNOSIS}

Although clinical diagnosis is significant, laboratory confirmation is important to distinguish from other diseases. It can be made by searching for specific antibodies (which appear few days after the beginning of clinical signs), and by isolating the agent from blood or skin biopsy samples and from ticks collected from the patients and reservoir animals. The isolation from blood and skin biopsy using cell culture is an early diagnosis because there are no antibodies in the blood during the rickettsemia stage (23).

Indirect diagnosis of spotted fever is based on serological reactions, and the main tests are: Weil-Felix, based on the agglutination of Proteus sp. antigens with ricketisial antibodies in guinea pigs; complement fixation; ricketsial toxins neutralization test in rats; latex agglutination; and IFAT, used in most laboratories as a standard diagnosis method. These tests, however, are not capable of distinguishing between rickettsial species in the isolate, because there is cross reaction between the members of one single group due to the high heterogeneity of stains and the large number of isolates not yet genetically classified (13). Other indirect detection test is enzyme-linked immunosorbent assay (ELISA) with monoclonal or polyclonal antibodies. However, these species-specific antibodies are only available for a limited number of stains $(7,14,28)$. 
Direct diagnosis of the agent can be made by direct fluorescent antibody test (DFAT), electron microscopy, and analysis of cytopathogenicity in VERO cells and pathogenicity in guinea pigs and embryo eggs. Rickettsia rickettsii can be visualized in the hemolymph test allowing a fast detection of the agent in infected ticks. Isolation of the agent from humans and arthropods can be obtained in VERO cells culture ( 7 , 14).

Polymerase chain reaction (PCR) has been shown useful in the detection and identification of pathogenic ricketisiae in different samples. With the development of automated nucleotide sequencers, analysis of sequences of amplified base products using PCR became fast and accurate. PCR can also be used to determine the genus and species of the agent $(7,14,27,28)$.

\section{TREATMENT}

The treatment of spotted fever is easy and inexpensive. It is based on antibiotic therapy and must be instituted immediately when there is clinical suspicion. If the disease is identified in the first days, prognosis is better, not fatal; however, lethality can achieve $80 \%(23,27)$.

Specific treatment must be instituted for all patients from endemic areas, with history of tick bite or contact with reservoir animals in the previous 15 days, and for those that present suspect clinical sings. Patients treated in the first days of infection can normally have clinical improvement in 24 to 72 hours (16).

Tetracyclines or cloranphenicol must be orally administered, daily, until three to four days after the disappearing of clinical signs. In extremely severe cases, the loading dose can be administered by intravenous route. Some fluoroquinolones such as ciprofloxacin seem to be efficient; however, sulfonamides are not indicated as they aggravate the clinical signs (3).

Antibiotics do not kill the agent but inhibit its growth, and the patients' immunological mechanisms are essential for the recovering, as well as the medical and nursing cares to possible complications, especially renal, cardiac, pulmonary, and neurological disturbances $(3,31)$.

\section{EPIDEMIOLOGICAL SURVEILLANCE}

The epidemiological surveillance must act together with health professionals to promote frequent qualification and alert to differential diagnosis (2). All suspect cases 
of Brazilian spotted fever must be notified to the Municipal Surveillance which in turn will notify the Epidemiological Surveillance of Regional Directories (DIRs) for conjoined investigation and control measures (16).

All suspect cases must have complete epidemiological record and material collected for specific diagnosis; also, they must be notified to the Superintendence for Endemic Disease Control [Superintendência de Controle de Endemias -SUCEN] which will investigate the presence of ticks and animals in probable places of infection and take additional control measures (16).

\section{PROPHYLAXIS}

There is no efficient vaccine against Brazilian spotted fever yet. The main prophylactic measure is to avoid contact with ticks. In endemic areas, ticks must be searched in the skin several times a day. The tick must be carefully removed, using heat to make it fall off the host and applying topic antiseptic solution at the sites to where it was adhered. Clamps can be used to remove adhered ticks (Figure 4) by fixing a clamp to their capitulum and pulling them off carefully. The ticks should never be pressed because this can lead to inoculation of the agent into skin lesions (16).

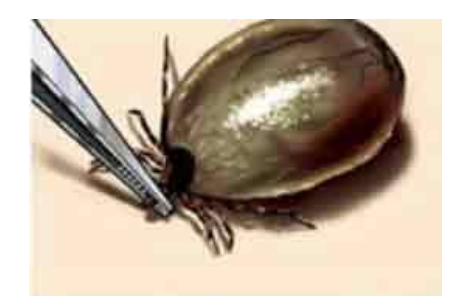

Figure 4. Tick removal using clamps (29).

\section{BRAZILIAN SPOTTED FEVER CONTROL ACTIONS}

Among the control actions against Brazilian spotted fever is the need to keep $A$. cajennense population controlled by using chemical control techniques in horse breeding. In areas of environmental preservation, capybara or tapir populations must be controlled, as the increase in the population of these wild mammals is directly proportional to the increase in the population of ticks. Walking in areas with confirmed presence of ticks must be avoided; however, when entering into such areas is necessary, the person should look for ticks in his/her body at intervals of two to three hours after walking because the faster a fixed tick is removed, the lower are 
the chances of infection; also, while walking, one must use physical barriers for the body, such as pants and boots fixed with adhesives, making difficult for ticks to climb the legs. Dogs kept in rural areas can use flea collar to prevent tick infestation. Dogs from urban areas that eventually have contact with rural areas need special care because they might have never been in contact with $R$. rickettsia, being thus more susceptible. Educational activities must be carried out in order to inform population about the risks of infestation by ticks and the measures to avoid possible contact with the transmitter (23).

\section{VECTOR CONTROL}

The control of ticks consists in the application of chemical products and management (even in the parasitism stage) of both the host and the environment. Almost all Ixodidae ticks are sensitive to climatic and environmental alterations such as low humidity and temperature. In open areas, the grass must be cut near the ground to reduce infestation by ticks as this allows higher penetration of sun rays, increasing temperature (16).

The pasture where animals like bovines and horses are raised must be in constant improvement, with removal of logs and other factors that can be favorable to the vectors development. For a more significant reduction in the number of ticks, the animals must receive insecticide application. However, the use of insecticides must be monitored to avoid resistance and to reduce environmental pollution. Birds, rodents and ants are tick predators in some areas and thus play an important role in reducing tick population (16).

Insecticides must be periodically applied to pets in order to prevent the latter from carrying infected ticks into the houses (16).

\section{CONCLUSION}

Brazilian spotted fever is a past and current zoonosis. The number of cases reduced in the 1940's due to the chemical control of vectors and the introduction of antibiotic therapy. Nowadays, it is increasing again, mainly in the states of the southeastern region of Brazil, demonstrating to be a reemergent disease.

This disease has public health importance. Although treatment is cheap and easy, Brazilian spotted fever still causes many deaths because of late diagnoses. Therefore, appropriate training of health and epidemiological surveillance 
professionals is needed to diagnose the disease as earliest as possible. Prophylactic, control and health educational actions directed to the general population are also important.

\section{REFERENCES}

1 ACHA PN., SZYFRES B. Fiebre maculosa de las Montañas Rocosas. In: ACHA PN., SZYFRES B. Eds. Zoonosis y enfermidades transmissibles comunes al hombre y a los animales. 3.ed. Washington: Organización Panamericana de La Salud, 2006: 16-22.

2 BRASIL. Ministério da Saúde. Fundação Nacional de Saúde. Guia de vigilância epidemiológica. Brasília: Ministério da Saúde, 2002.

3 BROOKS GF., BUTEL JF., MORSE SA. Riquetsioses. In: BROOKS GF., BUTEL J F., MORSE SA. Eds. Jawetz, Melnick e Adelberg Microbiologia Médica. 21.ed. Rio de Janeiro: Guanabara Koogan, 2000: 243-7.

4 CARDOSO LD., FREITAS RN., MAFRA CL., NEVES CVB., FIGUEIRA FCB., LABRUNA MB., GENNARI SM., WALKER DH., GALVÃO MAM. Caracterização de Rickettsia spp. circulante em foco silencioso de febre maculosa brasileira no município de Caratinga, Minas Gerais, Brasil. Cad. Saúde Pública, 2006, 22, 495501.

5 DEL GUERCIO VMF., ROCHA MMM., MELLES HHB., LIMA VCL., PIGNATTI MG. Febre maculosa no município de Pedreira, São Paulo, Brasil. Inquérito Sorológico. Rev. Soc. Bras. Med. Trop., 1997, 30, 47-52.

6 DIAS E., MARTINS AV. Spotted fever in Brazil: a summary. Am. J. Trop. Med. Hyg., 1939, 19, 103-8.

7 ESTRADA DA. Aplicação da reação em cadeia pela polimerase para detecção de riquétsias em carrapatos (Acari: Ixodidae) coletados no município de Campinas, São Paulo. Campinas: Universidade Estadual de Campinas, Instituto de Biologia, 2003. 57p. [Dissertação - Mestrado]

8 ESTRADA DA., SCHUMAKER TTS., SOUZA CE., RODRIGUES NETO EJ., LINHARES AX., Detecção de riquétsias em carrapatos do gênero Amblyomma (Acari: Ixodidae) coletados em parque urbano do município de Campinas, São Paulo. Rev. Soc. Bras. Med. Trop., 2006, 39, 68-71. 
9 FRANZ VON LICHTENBERG MD. Doenças Infecciosas. In: COTRAN RS., KUMAR V., ROBBINS SL. Eds. Patologia Estrutural e Funcional. 5.ed. Rio de Janeiro: Guanabara Koogan, 1996: 288-9.

10 GALVÃO MAM. A Febre maculosa brasileira em Minas Gerais e seus determinantes. Rio de Janeiro: Fundação Oswaldo Cruz, Escola Nacional de Saúde Pública, 1988. 186p. [Master's Thesis].

11 GALVÃO MAM., CALIC SB., CHAMONE CB., MAFRA CL., CESARINO FILHO C., OLANO JP., WALKER DH. Spotted fever rickettisiosis in Coronel Fabriciano, Minas Gerais State. Rev. Soc. Bras. Med. Trop., 2003, 36, 479-81.

12 GUEDES E., LEITE RC., PRATA MCA., PACHECO R., WALKER DH., LABRUNA MB. Detection of Rickettsia rickettsii in the tick Amblyomma cajennense in a new Brazilian spotted fever-endemic area in the state of Minas Gerais. Mem. Inst. Oswaldo Cruz, 2005, 100, 841-5.

13 GREENE CE., BREITSCHWERDT EB. Rocky mountain spotted fever, murine typhuslike disease, rickettsialpox, typhus, and $\mathrm{Q}$ fever. In: GREENE CE. Ed. Infectious diseases of the dog and cat. 3.ed. Philadelphia: Saunders-Elsevier, 2006: 232-45.

14 HORTA MC. Pesquisa de infecção por riquétsias do grupo da febre maculosa em humanos, eqüídeos, caninos e em diferentes estádios de vida de Amblyomma cajennense, provenientes de uma área endêmica do estado de São Paulo. São Paulo: Universidade de São Paulo, Faculdade de Medicina Veterinária e Zootecnia, Epidemiologia Experimental Aplicada às Zoonoses, 2002. 82p. [Master's Thesis] 15 LEMOS ERS., ROZENTAL T., VILLELA CL. Brazilian spotted fever: description of a fatal clinical case in the state of Rio de Janeiro. Rev. Soc. Bras. Med. Trop., 2002, $35,523-5$.

16 LIMA VLC., DEBERALDINI ER., SCARDAZZI MCF., ALMEIDA CAF., MAYO RC., SOUZA CE., RANGEL O., ALVES MJCP., OLIVEIRA SS., ROCHA MMM., GUERCIO VMF., MELLES HHB., NOUÉR SA., PAPAIORDANOU PMO., RAVAGNANI RC., RACHED ML., TEIXEIRA VLG., ALBUQUERQUE AC. Manual de Orientação para Vigilância Epidemiológica: febre maculosa. Campinas: Secretaria de Estado da Saúde, 1996.

17 LIMA VLC., SOUZA SSL., SOUZA CE. Situação da febre maculosa na região administrativa de Campinas. Cad. Saúde Pública, 2003: 331-4. 
18 LINCOLN MEDICAL END MENTAL HEALTHCENTER. Systemic Infectious Disorders. Lincoln Emergency Medicine, [serial online], 2006, [cited 2006 November 18]. Available from:

http://www.lincolner.com/Lincoln\%20page\%203/images/BoardReviewsystemicinfecti ons.htm.

19 MAGALHÃES O., MOREIRA JA. Typho exanthemático em Minas Gerais. Bras. Med., 1939, 37, 882-91.

20 MELLES HHB., COLOMBO S., SILVA MV. Febre maculosa: isolamento de Rickettsia em amostra de biopsia de pele. Rev. Inst. Med. Trop. São Paulo, 1992, 34, 37-41.

21 MSN ENCARTA: ONLINE ENCYCLOPEDIA, DICTIONARY, ATLAS, AND HOMEWORK. Rickettsia bacteria. MSN Encarta, [serial online], 2006, [cited 2006 November 18]. Available from: http://uk.encarta.msn.com.

22 NELSON RW., COUTO CG. Encefalite, mielite e meningite - doenças causadas por riquétsias. In: NELSON RW., COUTO CG. Eds. Fundamentos de Medicina Interna de Pequenos Animais. 2.ed. Rio de Janeiro: Guanabara Koogan, 1998: 7956.

23 PEREIRA M., LABRUNA MB. Febre maculosa: aspectos clínico-epidemiológicos. Rev. Clín. Vet., 1998, 12, 19-23.

24 PIZA JT. Considerações epidemiológicas e clínicas sobre o tifo exantemático de São Paulo. In: PIZA JT., MEYER JR., SALLES-GOMES L. Eds. Tifo Exantemático de São Paulo. São Paulo: Sociedade Impressora Paulista, 1932: 11-119.

25 RICKETTS HT. A microorganism which apparently has a specific relationship to Rocky Mountain spotted fever. J. Am. Med. Assoc., 1909, 52, 379-80.

26 SANGIONI LA. Pesquisa de infecção por riquettsias do grupo da febre maculosa em humanos, cães, eqüídeos e em adultos de Amblyomma cajennense, em região endêmica e não endêmica do Estado de São Paulo. São Paulo: Universidade de São Paulo, Faculdade de Medicina Veterinária e Zootecnia, Epidemiologia Experimental Aplicada as Zoonoses, 2003. 86p. [PhD Thesis].

27 SANGIONI LA., HORTA MC., VIANNA MCB., GENNARI SM., SOARES RM., GALVÃO MAM., SCHUMAKER TTS., FERREIRA F., VIDOTTO O., LABRUNA MB. Rickettsial infection in animals and Brazilian spotted fever endemicity. Emerg. Infect. Dis., 2005, 11, 266 -70. 
28 SANTOS AP. Aspectos epidemiológicos de febre maculosa em uma área endêmica do Município de Mogi das Cruzes (SP) e estudo em laboratório do ciclo de vida do vetor Amblyomma aureolatum (Acari: Ixodidae). São Paulo: Universidade de São Paulo, Faculdade de Medicina Veterinária e Zootecnia, Epidemiologia Experimental Aplicada às Zoonoses, 2003. 86p. [PhD Thesis].

29 SUPERINTENDÊNCIA DE CONTROLE DE ENDEMIAS. Informe técnico sobre febre maculosa [serial online], 2006, [cited 2006 October 17]. Available from: http://www.sucen.sp.gov.br.

30 TILLEY LP., SMITH JR FWK. Rocky mountain spotted fever. In: TILLEY LP., SMITH JR FWK. Five Minute Veterinary Consult: Canine and Feline. 2.ed. São Paulo: Manole, 2003: 1174-5.

31 TIRIBA AC. Doenças causadas por rickettsias. In: VERONESI R., FOCACCIA R. Tratado de Infectologia. São Paulo: Atheneu, 1999: 528-9.

32 URQHART GM., ARMOUR J., DUNCAN JL., DUNN AM., JENNINGS FW. Entomologia Veterinária. In: URQHART GM., ARMOUR J., DUNCAN JL., DUNN AM., JENNINGS FW. Parasitologia Veterinária. 2.ed. Rio de Janeiro: Guanabara Koogan, 1996: 161.

33 WALKER DH., RAOULT D. Rickettsia rickettsii and other spotted fever group Rickettsiae (Rocky Mountain spotted fever and other spotted fevers). In: MANDELL GL., BENNETT JE., DOLIN R. Eds. Mandell, Douglas \& Bennett's principles and practice of infectious diseases. 4.ed. New York: Churchill Livingstone, 1995: 1721-5. 